\title{
Az orvosok és a „népi demokratikus” átalakulás (1946. ősz-1948)
}

\author{
N. Szabó József dr. \\ Nyíregyházi Egyetem, Gazdálkodástudományi Intézet, Nyíregyháza
}

\section{Az orvosok a demokrácia kiépülésének időszakában *}

A nemzeti újjászületés és a politikai demokrácia kialakulásakor, 1945-ben a pártoknak tisztában kellett lenniük azzal, hogy olyan értelmiséget örököltek, amelynek nemcsak a hatalmi apparátushoz tartozó része, hanem egyes szakmai csoportjai is - eltérő módon ugyan, de kötődtek az előző rendszerhez. E bonyolult helyzet nagyon átgondolt értelmiségpolitikát kívánt meg a politikai elittől.

A Magyar Nemzeti Függetlenségi Frontba tömörült demokratikus erók a nemzeti újjáépítés 1944. decemberi meghirdetésekor az értelmiség - benne az orvosok részvételére is számítottak. A cselekvő magatartás azonban az értelmiségnek csak kisebb hányadát jellemezte, nagy része passzív maradt. Ennek elsődlegesen az volt az oka, hogy az értelmiségnek perspektívát ígérő demokratikus hatalom és a réteg között az 1945 tavaszán bevezetett igazolási rendelet miatt feszültség keletkezett. A demokráciának az értelmiség megnyerése mellett ugyanakkor fontos politikai érdeke volt a fasiszta érzületúek felelősségre vonása. Az Ideiglenes Nemzeti Kormány a korabeli nemzetközi antifasiszta intézkedésekhez hasonlóan több rendeletet hozott, ezek közé tartozott a közalkalmazottak, majd a magánalkalmazottak igazolásáról szóló, 1945 tavaszán megjelent rendelet. A rendelet alapvetô célkitûzéseinek megvalósítását azonban gyengítette, ső́t a végrehajtás során igen sok félreértésre adott lehetôséget, hogy a törvény nem tisztázta pontosan a népellenség fogalmát. Ez is hozzájárulhatott ahhoz, hogy például az orvosok $10 \%$-át feddésre vagy még súlyosabb büntetésre ítélték. Az eljárás során elkövetett visszaélések miatt az értelmiség nagy része - köztük az orvosok is - ellenségesen fogadta az igazolásokat. ${ }^{1} \mathrm{~A}$ po-

\footnotetext{
* Balázs Péter: Orvostársadalom-történelem amnéziával címú (Valóság, 1991. 9. sz.) kitűnő tanulmánya szélesebb történelmi kitekintésben járult hozzá az általam tárgyalt korszak differenciált megértéséhez. A kérdést részletesen tárgyalom N. Szabó József: Az orvosok és a rendszerváltás 1945-1946 (Egészség, 1996. 5. sz. 24-26. o.) című dolgozatomban, ezért a tanulmányban bizonyos kérdések bemutatásától eltekintettem.

${ }^{1}$ Magyar Közlöny, 1945. 1. sz.; Jakab Miklós: Társadalmi változás és a magyar értelmiség 1944-1948. Kossuth Könyvkiadó, Budapest, 1979. 124. o.
}

litikai bizonytalanság mellett a rossz körülmények és az alacsony életszínvonal is negatív hatást gyakorolt, ugyanis a háború utáni infláció a társadalom összes rétege közül az értelmiséget érintette a legsúlyosabban. Az értelmiség nagy részére ezért a közöny, valamint a Horthyrendszerben élvezett megbecsülés iránti nosztalgia volt jellemző. Az intelligenciát a két háború között a hatalmi elit egzisztenciálisan is magához kötötte, erkölcsi és szakmai elismerésben részesítette. Az orvosok helyzete az értelmiségiek közti összehasonlításban az egyik legjobb volt, többsége számára a rendszer polgári létet biztosított.

Az orvosok egy részének hozzáállása az előző rendszerhez azonban bonyolultabb volt, mint a többi szakmai csoport reagálása. A holokauszt, valamint a két világháború közötti különböző negatív intézkedések hatásai nem múltak el nyomtalanul a zsidó származású orvosoknál, aminek következményeként a politikai attitüd is másként jelentkezett körükben, mint keresztény társaiknál és más értelmiségi csoportoknál.

A háború befejezése utáni újjászületésben azonban nagy szükség lett volna az értelmiségi aktivitásra. A pártok között a politikailag legaktívabb Magyar Kommunista Párt (MKP) a szakmai csoportok közül kiemelt szerepet szánt a múszakiaknak. ${ }^{2}$ Kezdettól megkülönböztetett figyelemmel foglalkozott a tudományos és múvészeti kiválóságokkal. Az oktatási reform, valamint a nyolcosztályos általános iskola létrehozása előtérbe állította a pedagógusokat.

A magyar értelmiség szakmai csoportjai közül 1945ben az orvosok iránt nyilvánult meg a legkisebb érdeklődés. Annak ellenére, hogy az orvosoknak nem volt centrális politikai jelentőségük, a szociáldemokraták már 1945 elején hangsúlyozták a csoport társadalmi-politikai fontosságát.

A Magyarországi Szociáldemokrata Párt (MSZDP) Ideiglenes Intézóbizottsága nagy gondot fordított az orvosok széles körü szervezésére. Bán Antal vezető szociáldemokrata politikus szerint az orvosoknak a néptömegekre gyakorolt befolyása miatt számarányukat meghala- 
dó fontosságuk van a társadalmi-politikai életben. Az orvosok ügyével a különböző pártprogramok között először az 1945. február végén Kiss Sándor és Vatai László által készített kisgazdapárti programtervezetben találkozunk. A kisgazdatervezet az orvosokkal a megvalósítandó közegészségügyi reform kapcsán foglalkozott. A Nagy Ferenc által készített program is hasonló szempontból közelítette meg a kérdést. ${ }^{3}$

Az orvosok mellőzését azzal magyarázhatjuk, hogy a pártok többsége úgy ítélte meg: a viszonylag kis létszámú, az újjáépítésben és a politikai harcban központi szerepet nem játszó orvosoknak nincs olyan értelmiségpolitikai jelentőségük, mint a többi szakmai csoportnak. Az orvosok iránti érdektelenség továbbá azzal is összefügghetett, hogy a rendszerváltozás a háborús pusztítás miatti gazdasági katasztrófa körülményei között ment végbe, amely nem tette lehetővé egy szükségszerü, de pénzügyileg meg nem alapozott egészségügyi reform bevezetését. Az orvosok tevékenysége ezért szaktevékenységként sem értékelődött fel. A politikai harc kiéleződésével, az 1945-ös választások közeledtével ugyanakkor egyes pártok - köztük a Független Kisgazda-, Földmunkás- és Polgári Párt (FKgP) - részéról 1945 nyarától már politikai aktivitás is megnyilvánult a csoport iránt.

A kisgazdák egészségpolitikai kérdésekkel, az orvosok egzisztenciális problémáival, valamint a gyógykezelés és az orvosválasztás kérdéseivel kezdtek foglalkozni. ${ }^{4} \mathrm{Az}$ őszi budapesti törvényhatósági választások után az orvoskérdéssel kapcsolatosan az FKgP már politikai problémákat állított előtérbe. Legfontosabb követelésük az volt, hogy orvosi vezetéssel szervezzenek egészségügyi minisztériumot. Cseh-Szombathy László orvos-politikus azt indítványozta, hogy ismerjék el a mind ez idáig közérdekű munkák körébe sorolt orvosi tevékenységeket. ${ }^{5}$

A kisgazdaaktivitás egészségügyi-egészségpolitikai szempontokon kívül ekkor hatalmi kérdéseket is érintett. Annak megfogalmazása, hogy orvos vezetésű legyen az egészségügy, elsősorban a kommunista Molnár Erik elleni támadásként volt értelmezhető.

A Magyar Kommunista Párt az orvosok irányában kifejtett politikáját csak a párt gyenge társadalmi-politikai bázisát tükröző 1945. novemberi parlamenti választások után módosítja. Ennek lényege, hogy a kommunisták a parasztság megnyerésében játszandó szerepük miatt „nyitnak” az orvosok irányában. Ezután már fontosnak tartották az orvosok politikai megnyerését. Az MKP ezt követően önkritikát gyakorolva arra a megállapításra jutott, hogy eddig az orvosokkal nem társadalmi-politikai fontosságuknak megfelelően foglalkoztak. Az orvospolitika átértékelése elsősorban a földosztás idején földhöz jutott nincstelenek, valamint a két világháború közötti 1-3 holdas szegényparasztok tervezett megnyerésével

\footnotetext{
${ }^{3}$ Balogh Sándor-Izsák Lajos: Pártok és pártprogramok Magyarországon (1944 1948). Tankönyvkiadó, Budapest, 1977. 169-174., 175-184. o.

${ }^{4}$ Kis Újság, 1945. október 4.

Kis Újság, 1945. október 4.
}

volt összefüggésben. A párt a paraszti befolyás növelésével a számba jöhető értelmiségi csoportok között a körorvosokat és a tisztiorvosokat tartotta igen fontosnak. $\mathrm{Az}$ orvosok közötti népszerüség növelése érdekében az MKP ankétokat és gyúléseket kívánt rendezni. ${ }^{6}$

Néhány egészségügyi kérdéssel való foglalkozás ellenére a pártok mégsem tulajdonítottak megfelelő jelentőséget az orvosok speciális problémáinak. Pedig voltak nehézségek, melyeket Horányi Béla professzor a budapesti klinikák 1946. május 23-i gyúlésén ismertetett. A gyưlés résztvevői az orvostársadalom helyzetének javítása érdekében követelték a díjtalan állások megszüntetését (400 volt), a status rendezését, 3 év utáni véglegesítést, a kollektív szerződés szerinti fizetést és veszélyességi pótlékok bevezetését. ${ }^{7}$ A problémákra rávilágított a június elején megtartott Országos Orvoskongresszus is.

Az orvosok irányában kifejtett álláspontokat a politikai küzdelem döntötte el. A politikai életben 1946 nyarán ugyanis patthelyzet alakult ki azáltal, hogy a polgári alternatívát képviselő Független Kisgazdapárt és a baloldali átalakulást vezető Magyar Kommunista Párt között a küzdelem 1946 nyarán nem dőlt el.

A hatalmi vetélkedésben a baloldalnak a szegényparasztság állásfoglalása döntő fontosságú volt. Nem véletlen, hogy az orvoskérdés a politikai, elsősorban a kommunista vezetés érdeklődését felkeltette. Az MKP Értelmiségi Bizottsága titkárának 1946. augusztus 2-i jelentéséból látható, hogy a párt az orvosok politikai jelentőségét a paraszti befolyásolásban nagyra értékelte. Ennek megvalósítása érdekében az MKP a párt „parasztlapjában”, a Szabad Földben a jövőben behatóan kívánt foglalkozni a vidéki körorvosok ideológiai és gazdasági problémáival, és népszerüsítésükről is gondoskodni akart. ${ }^{8}$

Az orvosok megnyerése és politikai célzatú felhasználása 1946 nyarán azonban nem volt kellőképpen összekötve a csoport egzisztenciális és szakmai problémáinak rendezésével. Bár egyes újságok, köztük a Nemzeti Parasztpárt lapja, a Szabad Szó újságcikkeiben foglalkozott a problémával. ${ }^{9}$ A remélt siker nem véletlenül váratott magára, a problémák nagy része nem oldódott meg, és a Magyar Kommunista Párthoz való közeledés sem ment végbe. A kommunista orvospolitika sikertelenségével és a kérdésnek az MKP politikájában újólag játszandó fontos szerepével is magyarázható, hogy a Magyar Kommunista Párt Titkárságának 1946. augusztus 24-i ülése is foglalkozott a helyzettel, és kezdeményezte az orvosok problémáinak rendezését. ${ }^{10} 1946$ késő nyarától a kommunisták részéről az orvosok mint véleményformáló csoport felértékelődtek és politikailag fontossá váltak. Mindezek ellenére azonban nem lettek a „nagypolitika”

\footnotetext{
PTI Archívum 274-24/2.

Szabad Szó, 1946. május 24.

PTI Archívum 274-24/2

Szabad Szó, 1946. június 18., szeptember 14

${ }^{10}$ PTI - Arch. Titk. Fj. 682
} 
centrális részéhez kapcsolt csoporttá. A redisztribúcióból sem úgy részesültek, mint a meghatározó rétegek. A különböző preferenciák sem úgy fogalmazódtak meg, mint a politikailag kiemelt értelmiségieknél. Ugyanakkor több, az orvosok elleni támadás 1946-ban felerősödött egyes baloldali lapoknál, így többek között a Szabadságnál. ${ }^{11}$ Május 1-jén megjelent az 500/1946. számú ME „tisztogatási” rendelet, mely szerint június 5-ig kell a minisztereknek megállapítaniuk, hogy a tárcájuk körébe tartozó intézmények létszámából hány fót kell elbocsátani. A közigazgatás megtisztításáról szóló, 1946 májusában megjelent bélistarendelet nem volt olyan szigorú, mint más köztisztviselők elleni fellépés. A bélisták végrehajtása során mintegy 60000 személyt, többségükben hivatalnokot távolítottak el. Azonban orvosokat is ért támadás.

Az orvosokat ért baloldali politikai kihívásokkal a Független Kisgazdapárt nem értett egyet, azokat határozottan visszautasította. A párt orvoscsoportjának vezetője, Reök István az orvosok bélistázásának politikamentes elbírálását kérte. A kisgazda orvoscsoport szerint az orvosok elleni fellépés nemcsak a réteg egzisztenciáját, hanem az egészségügyi ellátást is veszélyezteti! A Független Kisgazdapárt abban reménykedett, hogy egy olyan szakmai csoportnál, amelyben a tevékenység gyakorlásakor a politikai elem nem meghatározó a szakelem mellett, a szakmaiság hathatós ellenérv lehet a politikai-ideológiai támadással szemben. ${ }^{12}$

\section{Szakítás a demokráciával}

Nemcsak a „nagypolitikában”, hanem az orvospolitikában is jelentős változás történt az MKP 1946. szeptember 29. és október 1. között megtartott III. kongresszusán. A párt ugyanis szakított az addig általa is többé-kevésbé betartott, szabad választásokon alapuló, többpárti parlamentáris demokrácia játékszabályaival, amikor deklarálta: „ki a nép ellenségeivel a koalícióból”. ${ }^{13}$ A kommunisták a pártértekezleten ezzel döntöttek a pluralizmus felszámolásáról, a polgári erőknek a hatalomból való kiszorításáról. A Magyar Kommunista Párt ebben a harcban bízott a paraszttömegek támogatásában. A párt a szegényparasztság megnyerését szem előtt tartva alakította ki parasztpolitikáját és formálta az orvosokhoz való viszonyát. A párt azt feltételezte, hogy társadalompolitikai befolyását úgy szélesítheti, ha növeli a parasztságra gyakorolt befolyását, amit az orvosok megnyerésén keresztül vélt elérhetőnek.

Az orvosok közti befolyás növelését azonban nehezítette a csoport súlyos gazdasági helyzete, az egészségügy katasztrofális problémái és az orvosok egy részének a

\footnotetext{
11 Szabadság, 1946. június 2.

12 Nemzetgyúlés Naplója III. kötet. Hiteles Kiadvány, Budapest, 1951. 115116. o.

13 A Magyar Kommunista Párt és a Szociáldemokrata Párt határozatai 1944 1948. Kossuth Könyvkiadó, Budapest, 1967. 272. o.
}

kommunistákétól eltérő politikai felfogása és érdeke. A kommunisták 1946 nyarának végén mindezekkel tisztában lehettek, mert ennek ismeretében kezdtek az orvosok felé fordulni. A III. kongresszus és a párt akcióprogramja azonban nem tükrözte ezt a változást. Az orvosokkal a kommunisták nem a parasztság megnyerésének fontosságával kapcsolatos megközelítéssel foglalkoztak. Az MKP Értelmiségi Osztályának 1947. február 1.--március 31-i munkatervében azonban a 3 éves tervvel és az 1947 elején „leleplezett” összeesküvéssel kapcsolatosan az orvosok már szerepet kaptak. A változás része volt, hogy február 10-ig létre kívánták hozni a kommunista orvoscsoport vezetőségét, és frissíteni szándékozták a szakszervezeti vezetőséget három kommunistával. Továbbá szoros kapcsolatot akartak kialakítani az orvosszakszervezet és a Népjóléti Minisztérium között. A tervezetben szerepel, hogy március 15 -ig orvosklubot kell felállítani, és 4-6 tagú, szakorvosokból álló falujáró csoportot kell szervezni, továbbá ki kell szélesíteni az üzemorvosi akciókat. Feladatként lett megfogalmazva a kommunista gyógyszerészek és fogorvosok budapesti aktívájának a megszervezése is. ${ }^{14}$

Az MKP 1947 tavaszától az orvosokkal kapcsolatosan a hangsúlyt a falujárás fokozására, a párttagok számának növelésére és a szakszervezeti befolyás kiszélesítésére kívánta koncentrálni. A párt orvoscsoportjának júliusi jelentéséből látható, hogy az MKP taglétszáma erőteljesen növekedett. Ennek okát az orvoscsoport a falujárás hatalmas mértékű kiszélesítésére vezette vissza. A pünkösdi falujárásban 200 orvos vett részt, amelynek következménye volt a taglétszám növekedése. Debrecenben például 35-rôl 52-re, Pécsett 24-rôl 32-re nőtt az MKP-tagok száma. Ezzel 1800-nál több párttag orvos lett Magyarországon. A nyár folyamán lépett be az MKP-be az MSZDP-tól távozó Kettesy Aladár professzor is. Kettesyn kívül az MSZDP-ból jött Takács Zoltán kórházigazgató, valamint Lénárt Ferenc és Hoffmann Ferenc. Pártonkívüliből lett MKP-tag Rády Ödön tisztifőorvos és Maróthy Jenő kórházigazgató, valamint Röttler István és Batizfalvi János. Az FKgP tagja volt korábban Hernádi Miklós. Ekkor lett a Magyar Kommunista Párt tagja 5-6 egyetemi magántanár is. ${ }^{15}$

Az MKP számára a „pozitív” elmozdulás mellett a belépésekkel kapcsolatosan problémák is keletkeztek. 1947. augusztus 2-án a belépések miatti feszültségről Weil Emil, az Országos Közegészségügyi Tanács elnöke Révai Józsefnek jelentést készített. Az elnök úgy látta, hogy a pártba belépett orvosok egy részének múltját egy-egy fasiszta hangú cikk vagy beszéd terheli, ugyanakkor azt is megjegyzi, hogy sok esetben elég gyorsan meggyőződéses párttagokká, jó szervezőkké váltak az újonnan belépők. A jövővel kapcsolatosan azt a véleményt fogalmazta meg Weil Emil, hogy a szimpatizálókat be kell léptetni a

\footnotetext{
14 PTI Archívum 274 f. 24/2. öe.

15 PTI Archívum 274 f. $24 / 4$. öe.
} 
MKP-ba, mert csak párton belül tudják óket összefogni és megnevelni. ${ }^{16}$

A Kommunista Orvoscsoport 1947 őszétől megnőtt, csírái azonban már a szakszervezet megalakulásától, az Orvos-Egészségügyi Dolgozók Szakszervezetének háború utáni létrejöttétôl jelen voltak. Weil Emil, Simonovits István és Zádor Imre alapították a szakszervezetet, amelyben munkájuk kezdetén a szervezeti munkát öszszekapcsolták a pártmunkával. A szakszervezeti és egyéb kulcspozíciókat kommunistákkal kezdték betölteni. Az orvosszakszervezet elnöke Weil Emil, titkára Simonovits István, jegyzője pedig Zádor Imre lett. Az orvosszakszervezetben és a népjóléti tárcánál is erős volt a kommunisták pozíciója. A szakszervezetben a professzorok közül tagok voltak: Gegesi Kiss Pál, Petényi Géza, Rusznyák István, Rajka Ödön és Gorvai György. A tisztiorvosok köréból pedig: Bakács Tibor, Arató Ottó, Balassa Sándor. A minisztériumban Simonovits István, Pollwer György, Dubovitz Dénes, Rottenbiller Alajos és Kun Miklós voltak az MKP tagjai.

A kommunisták nemcsak azáltal voltak erősek, hogy a szakszervezetben meghatározó szerepet játszottak, hanem azért is, mert a szakszervezetból irányították az egyetemi és kerületi kommunista orvosokat. Arra törekedtek, hogy a szakszervezetbe állandóan újabb és újabb erőket vonjanak be. A szakszervezet erőfeszítésének köszönhetően sikerült bevonni többek között Kaczander Gyulát, Réti Endrét, Debröczi Tibort, Kaiser Frigyest, Demény Évát, Biró Lászlót, Wittmann Lászlót, Ákos Károlyt, Várhelyi Józsefet és Harsányi Jenőt. Az Orvos Szakszervezet első kádereit azokból az orvosokból állították össze, akik régi pártmunkások voltak, vagy akik a Szociáldemokrata Párt orvoscsoportjában tevékenykedtek. A beszámolóból azt is megtudjuk, hogy a kiváló szakemberek közül a legmegbízhatóbbakat léptették be a pártba.

Az Orvos Szakszervezetben elért pozíciókat az orvosok közötti állandó szervezőmunkával igyekeztek alátámasztani, ezenkívül foglalkoztak a gazdasági természetű problémákkal is. A párton kívüli orvosok közötti „házi” agitációval próbálták a kommunista orvosok létszámát állandóan emelni és az orvosok közötti tekintélyüket növelni. Az 1947. augusztus 31-i választások idején 2700 orvos tagja volt a Magyar Kommunista Pártnak. Különösen nagy volt a létszámnövekedés vidéken, a kampány alatt 90\%-kal emelkedett az MKP-tagok száma. ${ }^{17} 1948$ tavaszán az MSZDP felbomlasztása kapcsán a kommunista agitáció és a „helyezkedés” révén 42 „átlépés” történt az MKP-ba. Az Orvos Csoport nemcsak az orvosok beszervezésével ért el eredményeket, hanem a pedagógusok megnyerése terén is. Ennek következményeként 9 pedagógust sikerült a Magyar Kommunista Pártba beléptetni. ${ }^{18} \mathrm{Az} \mathrm{MKP}$-ba való beléptetés az MSZDP bom- lasztása, a pártegyesülés, az Magyar Dolgozók Pártja (MDP) létrehozásának közeledtével már nem volt olyan egyértelmúen „pozitív”, mint 1947 őszén.

Az Értelmiségi Osztály ugyanis a Szervező Bizottságnak 1948. április 22-én küldött megjegyzésében már a szervezési módszer felülvizsgálatát javasolta, többek között azért, mert az orvoscsoport munkája nem volt egybehangolva a pártszervezettel. Azt is megállapította, hogy az orvosszervezés során sok „fasiszta” elem került a pártba. A párt politikájának eltorzulása következtében 1948 tavaszán a fasiszta terminológia már a polgári demokrácia talaján állók egy részét is magában foglalta. Végezetül arra a megállapításra jutottak, hogy az orvoscsoportnak revízió alá kell vonnia mind a szakszervezeti, mind a pártvonalon az eddigi koncepcióját, és a pártra nézve káros elemeket izolálni kell. A bizottság ezért azt is javasolta, hogy a rövidesen létrejövő Magyar Dolgozók Pártja tagsági könyveinek kiosztásakor az orvosok között jelentős számú elemet ki kell hagyni a pártból. ${ }^{19}$

Egy másik vélemény szerint a volt „fasiszták” beléptetésére szükség volt. Ezt azzal magyarázták, hogy bár az 1947-es választások hatására nagy számban léptek be az MKP-ba, ennek ellenére a pártban és az Orvos Szakszervezetben megmaradt a régi elemek befolyása. Példaként említették Szekszárdot, ahol 1948. március elején az Orvos Szakszervezet közgyúlésén Tóth Sándor igazgató éles hangon támadta a pártot. Ezt az esetet a kommunista orvosok azért tartották veszélyesnek, mert a kisgazdapárti igazgatónak nagy hatása volt az orvosokra. A „régi elemek" befolyásával függhetett össze, hogy az MKP nagyméretü tagtoborzást hajtott végre Szekszárdon április 4. és 18. között. Ennek eredményeként a kórház 100 alkalmazottja és orvosa lépett be a pártba. ${ }^{20}$

Az MKP számára rossz politikai helyzet megváltoztatása érdekében az Orvos Szakszervezet részéról két kommunista vezető Szekszárdra utazott, ahol a kommunista cél elérése érdekében nyomásgyakorlást és zsarolást egyaránt igénybe vettek. Kijelentették, hogy aki nem foglal állást a demokrácia (népi demokrácia) mellett, annak nincs helye a közegészségügy szolgálatában. A „legvilágosabb" állásfoglalás az igazgatóval kapcsolatosan pedig az volt, hogy ha belép az MKP-ba, akkor maradhat közalkalmazott. Ennek ellenére Tóth Sándor ezt az ultimátumot elutasította. A helyzet fonákja volt, hogy ebben a kiélezett helyzetben az orvosok Tóth Sándor igazgató mellé álltak. Tették ezt annak ellenére, hogy az Orvos Szakszervezet kommunista küldöttei kijelentették: „repülni fognak”.

Április 4-én újra „lementek” Szekszárdra, ahol közben elterjedt, hogy a jobboldal „kidől”, aminek hatására elkezdődött az MKP-ba való tömeges belépés. A Magyar Kommunista Pártba való belépés túlságosan „jól” sikerülhetett, mert Bacsó Ferenc azt javasolta a Szervezési

\footnotetext{
16 PTI Archívum 21. $2+4$ f. 24/4. öe.

17 PTI Archívum 274 f. $24 / 4$. öe.

18 PTI Archívum 274 f. 24/4. Öe.
} 
Osztálynak, hogy utasítsa a megyei bizottságot a belépett tagok felvilágosítására és a „fasiszták” kizárására. Bacsó felhívta a budapesti orvoscsoport figyelmét a helytelen szervezési módszerek felülvizsgálatára. ${ }^{21}$ Mivel 1946 végétől az MKP értelmiségpolitikájában az „orvoskérdés" centrális szerepet játszott, a csoportról a legfelső pártvezetés - élükön Révai Józseffel - mindenről tudni akart. Az orvosok politikai felfogásában bekövetkezett változásról Weil Emil 1948. május 21-én informálta a Magyar Kommunista Párt föideológusát és kultúrpolitikai vezetőjét. Az Országos Közegészségügyi Tanács és az Orvos Szakszervezet kommunista elnöke úgy látta, hogy az orvosokat az 1947-es választások előtt a fizetés, a status, a praxis, a közvetlen anyagi kérdések foglalkoztatták, s legfeljebb még a saját osztály vagy a laboratórium fejlesztése érdekelte őket. Weil most viszont már úgy látta, hogy az orvosok megváltoztak ezekben a kérdésekben, állandó támadásokat intéztek az MKP ellen, és nem akarták megérteni, hogy az egészségügyi intézményeket csak lassanként lehet helyreállítani; nem akartak tudomást venni a népi demokrácia anyagi nehézségeiről, és csak nehezen lehetett érdeklődésüket az országos fontosságú egészségpolitikai kérdésekre irányítani. Az „orvosreagálás” megváltozásának okát 1948. május végén Weil Emil abban is látta, hogy az értelmiség az MSZDP jobboldalának befolyása alatt állt, és nem bízott a népi demokrácia állandóságában.

A kritika után ugyanakkor - az addigi megállapításoknak kissé ellentmondva - azt a következtetést vonta le, hogy a választások alatt és után az intelligencia mindinkább belátta, hogy az országot a Magyar Kommunista Párt építi, és ezért féltik egzisztenciájukat, és aggódnak saját sorsuk iránt. Weil Emil szerint a kommunisták 1947. október óta meglepetésszerűen vették észre, hogy míg addig a gyưlések megrendezésére minden erőt meg kellett mozgatni, most egyre látogatottabbá váltak a kommunista rendezvények. Úgy látta, hogy egy-egy gyưlésükön a város úgyszólván valamennyi orvosa ott volt, az aktívákon pedig valamennyi párttag megjelent, és az előadásokat feszült figyelemmel hallgatta végig. Az orvosok és a Szociáldemokrata Párt viszonyát a kommunista orvos-politikus úgy ítélte meg, hogy az MSZDP jobboldalának összeomlása az értelmiséget mélyen megrendítette, ezért igyekeztek a fúzió előtt a Magyar Kommunista Pártba átlépni.

A továbbiakban Weil úgy ítélte meg, hogy a szakcsoportokban, a tudományos testületekben az élet felélénkült, a politikai kérdések iránt az érdeklődés megnövekedett. Meglátása szerint az orvosok túlnyomó része ezért arra állítja be az életét, hogy Magyarországon szocializmus lesz, igyekszik megbarátkozni a helyzettel, bár zavarja, és nehezen tudja elképzelni a magánpraxis teljes megszünését, és attól is félnek, hogy életnívójuk viszony- lag alacsony marad. Weil Emil a Révainak küldött jelentést úgy zárja, hogy az értelmiség magatartása határozatlan, de nem rossz irányú. ${ }^{22}$

\section{Az orvosok származása - politikai és vallási megoszlása}

1948. május 31-re elkészült egy jelentés az orvosok származásáról, vallási összetételéről és politikai orientációjáról. Ebből megtudjuk, hogy 1948-ban Magyarországon körülbelül 9500 orvos volt, ebből Budapesten 5000 élt, a többi vidéken lakott. A budapesti orvosok $60 \%$-a, a vidéki orvosok $20 \%$-a volt zsidó származású, illetve vallású. A keresztény orvosok egy-két kivétellel az 1919 augusztusában alapított baloldalellenes Magyar Orvosok Nemzeti Egyesületének voltak tagjai. 1945 elején még létezett, de az Ideiglenes Nemzeti Kormány az első intézkedései között megszüntette az Orvosi Kamarát. A jelentés feltárta azt is, hogy az orvosok 10\%-a az igazolások előtt feddésre lett ítélve. A párttagértelmiséggel kapcsolatosan információt kapunk arról, hogy az 1947-es augusztusi választások előtt az orvosok körében a Magyar Kommunista Pártnak Budapesten 1100, vidéken 650 tagja volt. A beszámoló az orvoscsoport összetételét nem tartotta kielégítőnek, mert szakmai tekintély a kommunisták között csak elvétve akadt, ezek legnagyobb része is a zsidók közül került ki. A keresztény értelmiség viszont távol tartotta magát az MKP-tól, aminek magyarázatát a jelentés abban látta, hogy a párttagok féltek a vidéki értelmiségi társaság „bosszújától”.

Az augusztusi választások alatt a kommunista orvoscsoport tagjainak száma Budapesten 1500-ra, vidéken 1250-re nőtt, az egész országban pedig összesen 2750re emelkedett a párttagok száma. Kedvezően változott az MKP szempontjából az orvoscsoport azért is, mert szakmailag kiváló, nagy tekintélyú és kedvelt orvosok is kerültek a pártba. Pozitív változásként értékelte a felmérés azt is, hogy a párttagok fele már keresztény volt, továbbá azt is fontosnak tartotta, hogy a Szociáldemokrata Párt Orvoscsoportjának fölénye, befolyása az értelmiség felé megtört. A Magyar Kommunista Párt befolyásának növekedését abban látta a jelentés, hogy az Értelmiségi Osztály irányításával a választásokra határozott tervet dolgoztak ki, amelyet végre is hajtottak. Célul tűzték ki az értelmiség ellenállásának megszüntetését, különösen fontosnak tartották a falusi orvosokhoz való „hozzáférést”. Az Értelmiségi Osztály úgy ítélte meg, hogy ha a múltban kisebb hibákat elkövettek is, most már nem zárkóznak el az orvosok elől. Az „új” politika eredménye, hogy a választások óta eltelt fél évben Budapesten 200, vidéken pedig 400 orvos lépett be Kommunista Pártba.

A kommunista politika felülvizsgálatának része volt az is, hogy a választások után a párt megszüntette az aktív 
szervezkedést, és a hangsúlyt az új párttagok átnevelésére helyezte. Ez azzal is összefüggött, hogy a két munkáspárt egyesülése előtt földcsuszamlás történt a pártbelépés területén. Budapesten 600-an, vidéken szintén 600-an léptek be az MKP-ba. Az új párttagok többsége az 1927-ben alapított, majd 1950-ben megszüntetett Országos Társadalombiztosítási Intézet (OTI), valamint a szintén 1927-ben létrehozott és 1948-ban felszámolt Magánalkalmazottak Biztosító Intézete (MABI) tagja volt. A tagzárlat után csak Szekszárdon léptettek be, illetve akartak beléptetni újabb orvosokat a pártba, mert a tolnai megyeszékhely kórházában mindösszesen 4 kommunista párttag volt. Az egyesülés előtti tagzárlat óta viszont már nem a beléptetés, hanem a jelentkezők viszszautasítása okozott gondot. 1948. május végén Budapesten már 2500 orvos volt az MKP tagja, vidéken pedig 2025 fó. A magyar orvosok nem egészen 50\%-a ekkor már párttag lett. A Magyar Kommunista Párt azzal számolt, hogy a két munkáspárt egyesülése után a bekerüló szociáldemokrata orvosokkal együtt 65\% lesz az MDP-s párttagok aránya.

1948. május végén az MKP úgy látta, hogy az 1947-es választások után a taglétszám minden aktívabb beavatkozás nélkül, spontán „átszivárgásokkal” növekedett, illetve ott léptek be nagyobb számban orvosok a szervezetbe, ahol valamilyen okból, például más rétegekben tömeges belépés történt a pártba. A választások után az orvosok részéről több panasz érkezett a Szociáldemokrata Párt jobboldaláról azzal kapcsolatosan, hogy „beszervezésük" többször erôszakos volt. A Magyar Kommunista Párt elismerte, hogy a vezető orvosokkal hosszabb ideje foglalkozó elvtársak igyekeztek pressziókat gyakorolni. Ennek egyik magyarázatát az orvoscsoport abban látta, hogy a háború után az egyetemekrôl eltávolított "fasiszta” professzorok helyett az MSZDP jobboldala saját professzorokat „hozott be” az egyetemekre. A kommunista orvoscsoport szerint a „régi reakciós” professzorok helyett újonnan kinevezett reakciós orvosprofesszorok kerültek, így Melly József, Földvári Ferenc és Nánay Tibor egyetemi tanárok. A kommunisták szerint eltávolításuk napirendre került.

A budapesti orvoscsoport tagjait átvizsgálva a jelentés megállapította, hogy az 1947 júniusáig belépett 1100 orvos párttag közül 65 ellen a háború elő́tti múltjára vonatkozóan „terhelő” adatot találtak. Az igazoló bizottság feddésre ítélt 21 orvost, a maradék 44 ellen pedig olyan természetû adatokat talált, amelyek miatt az igazoló bizottság súlyosabb ítélete lett volna indokolt. A választások alatt belépett 400 orvos közül 25-tel kapcsolatosan rendelkeztek adatokkal, ezek között 22 olyan párttag volt, aki ellen az orvoscsoport szerint feddésnél súlyosabb ítéletre lett volna szükség.

Az 1947-es választások előtti vidéki orvos párttagokat értékelve arra a megállapításra jutott a jelentés, hogy a 650 orvos közül 80-nál volt jobboldali múltra utaló igazoló adat. A választások alatt belépett 600 orvos közül 57-et jobboldali múltúnak találtak. A „földcsuszamlás” után belépett 600 vidéki orvos közül 84-nek „volt” jobboldali múltja. A pártba belépó orvosok egy része nagy nyomás hatására lépett be a Kommunista Pártba, illetve lépett át az MSZDP-ből az MKP-ba. A kommunisták erôszakos átléptetéséről szól Kondrai Geró 1947. augusztus 17-i vallomása. Ebben a mátészalkai megbízott fóorvos arról számolt be, hogy megjelent nála Kaczander Gyula, az Országos Szakszervezet vidéki titkára, aki Tariska István volt illegális debreceni kommunista orvossal történt megbeszélésre hivatkozva felszólította, hogy lépjen be a Kommunista Pártba, mert csak abban az esetben remélheti főorvosi kinevezését, ugyanakkor ki kellett volna lépnie a Szociáldemokrata Pártból. Kondrai azt állította, hogy Kaczander Gyula erőszakossága miatt írta alá az MKP-ba való belépését. Ugyanakkor a burkolt fenyegetés ellenére sem volt hajlandó kilépni az MSZDP-ből..$^{23}$

Kondrai vallomását Kaczander titkár szeptember 17 én tagadta. Az erőszakos beléptetést „cáfolta” egy 1947. szeptember 16-i jelentésében a Magdolna Városi Kórház MKP üzemi titkára is, amit a Magyar Kommunista Párt Központi Titkárságának küldött. A kórházi párttitkár szerint két fóorvos, továbbá Náray és Venkey egyetemi magántanárok a kommunista agitáció révén és nem a fenyegetés hatására léptek be a pártba. ${ }^{24} 1947$ szeptemberében tovább folyt a belépésről, illetve a beléptetésről a polémia.

Weil Emilhez szeptember 27-én „cáfolatok” érkeztek arról, hogy erőszakos átléptetés történt volna. Több nyilatkozattal „megerősítették”, hogy az MKP-ba önkéntes volt a belépés. $\mathrm{Az}$ orvoscsoportot szeptember 18-án Lehner Imre egyetemi magántanár arról informálta, hogy a pártba történő belépése teljesen „önkéntes” volt. Nyilatkozatok tucatja jelent meg, amelyben orvosok kijelentették, hogy „önként” léptek be a Magyar Kommunista Pártba. ${ }^{25}$

Az „önkéntességet” cáfolta az MSZDP Központ Orvoscsoportjának vezetősége, amelyben jelezte, hogy az Orvos Szakszervezetben és az Egészségügyi Alkalmazottak Szakszervezetében a kommunista frakció gátlástalan pártmunkát végzett. Ennek egyik formája volt, hogy a kommunisták az MSZDP-párttagokat az MKP-ba való átlépésre igyekeztek rávenni. Az MSZDP Orvoscsoportjának vezetősége megjegyzi, hogy augusztus 14-28. között 12 megyei, illetve városi tisztifőorvost ilyen erôszakos úton léptettek át az MKP-ba. A szociáldemokrata vezetók arról is beszámoltak, hogy nemcsak a kommunista szakszervezeti funkcionáriusok, hanem a Népjóléti Minisztérium tisztviselói, köztük Molnár Erik miniszter is gyakorolta ezt az erőszakot alkalmazó módszert. Példaként említi, hogy a Népjóléti Minisztériumhoz tartozó Angyalföldi Elmegyógyintézet szociáldemokrata párti vezetóit arra figyelmeztették, hogy ha 24 órán belül nem

\footnotetext{
${ }^{23}$ PTI Archívum 274 f. 24/6. Öe.

24 PTI Archívum 274 f. 24/6. öe.

25 PTI Archívum 274 f. 24/6. öe.
} 
lépnek át a Kommunista Pártba, a kórházat megszüntetik. A durva nyomásnak engedve Nyírő Gyula professzor vezetésével a fóorvosi kar kollektíve átlépett a kommunistákhoz.

A szociáldemokrata orvoscsoport ebben a helyzetben úgy látta, hogy más megoldás nincsen, mint pozíciószerzés a Népjóléti és a Belügyminisztériumban, mivel ebben a két minisztériumban minden pozíció a kommunisták kezében van. Arról is informálták az MSZDP vezetőségét, hogy az elmúlt hetekben a szakszervezeti tiszti kar és a tisztviselői kar átlépett az MKP-ba, ami a korábbi paritást felborította. Mindezért az Orvos Szakszervezet és az Országos Közegészségügyi Tanács elnöke, a kommunista Weil Emil a felelős. ${ }^{26}$ Mivel a szociáldemokrata orvoscsoport legfontosabb feladatának tartotta a kommunista térhódítás és pozíciószerzés megakadályozását, a kommunisták arra koncentráltak, hogy a jobboldali szociáldemokratákat kiszorítsák, és a baloldaliakat megnyerjék. Az MKP orvoscsoportja az 1948. február l. és 1948. május 1. közötti időre munkatervet készített, amelyben a legfontosabb feladatnak az MSZDP orvoscsoportja baloldali vezetőinek megnyerését tartotta, továbbá közös aktívák tartásával a szociáldemokrata orvosokat magukhoz kívánták vonzani.

A kommunista „orvosszerzés” célja volt továbbá, hogy az orvoscsoport taglétszámát 200 újabb fővel növeljék, valamint, hogy havonta „végighallgassák” valamennyi párttagjukat és az, hogy a kerületi aktívák folytassák a szimpatizánsok rendszeres meghívását és az MSZDP-vel közös értekezletek rendezését.

Az orvospolitika célja volt az is, hogy ott szerezzenek pozíciókat, ahol az MKP nem tudta keresztülvinni célkitűzéseit. Ilyen volt a Vallás és Közoktatási Minisztérium (VKM) egyetemi ügyosztályán az orvosi ügyek referenciája. A „káderpolitika” terén a budapesti és a vidéki egyetemekre két kommunista professzor kinevezését tartották kívánatosnak, továbbá igazgatói állást kívántak szerezni a Posta Betegbiztosítási Intézetben, valamint a Magyar Biztosítási Intézetben. Ezenkívül az Orvos Szakszervezetbe újabb 200 tagot terveztek beszervezni. Az MKP káderpolitikáját úgy kívánták alakítani, hogy Kaposváron és Szegeden új kommunista többségü vezető-

${ }^{26}$ PTI Archívum 274 f. 24/6. öe. ségét „válasszanak”. Debrecenben pedig segítséget kívántak nyújtani a klinikai választásnál. ${ }^{27} \mathrm{Az}$ MKP bomlasztó politikájának „sikerét” jelzi, hogy az MKP pécsi pártbizottsága orvoscsoportjának vezetője az MSZDP felbomlasztását jelenthette a Központi Vezetőség (KV) Értelmiségi Osztályának. Az agitáció eredményeként 42 átlépés történt az MSZDP-ből a kommunista pártba. ${ }^{28}$ Ebben az akcióban kiemelt szerepet kapott Szekszárd. A tolnai megyeszékhely fontosságát az adta, hogy 1948. február közepéig a szekszárdi kórház vezetője a nagy tekintélyú, a Kisgazdapárt jobboldalához tartozó Tóth Sándor volt. A kommunisták nagy problémája volt továbbá az is, hogy a kórház 170 alkalmazottjából mindösszesen volt $10 \mathrm{MKP}$-tag.

A helyzet megváltoztatása érdekében 1948. február 16-án az Orvos Szakszervezet részéről lementek Szekszárdra. Itt kijelentették, hogy aki nem foglal állást a demokrácia (népi demokrácia) mellett, annak nincsen helye a közegészségügy szolgálatában. A legvilágosabb követelés pedig Tóth Sándor felé az volt, hogy lépjen be az MKP-ba, amit azonban a kórház vezetője elutasított. A kiélezett helyzet ellenére az orvosok vezetőjük mellé álltak. Ezután az Orvos Szakszervezet küldöttei kimondták, hogy „repülni” fognak. A kommunista erőszakosság hatására, valamint a politikai terror fokozódása következményeként olyan hírek terjedtek, hogy a „jobboldal kidől”, aminek hatására elkezdődött Szekszárdon is a tömeges belépés a kommunista pártba.

A helyzet ellentmondásosságára utal ugyanakkor, hogy az Orvos Szakszervezet javasolta a csoportosan belépett tagok felvilágosítását és a „fasiszták” kizárását és a helytelen szervezési módszerekkel való szakítást. ${ }^{29}$

(N. Szabó József dr., Nyíregyháza, Sóstói u. 31/B, 4400 e-mail: n.szabo.jozsef@nye.hu)

\footnotetext{
27 PTI Archívum 274 f. 24/2. öe.

28 PTI Archívum 274 f. 24/4. öe.

${ }^{29}$ PTI Archívum 274 f. 24/4. öe.
} 